\title{
Examining the teachers' pedagogical knowledge and learning facilities towards teaching quality
}

\author{
Muhd Zulhilmi Haron', Mohd Muslim Md Zalli², Mohamad Khairi Othman ${ }^{3}$, Mohd Isha Awang \\ ${ }^{1,3,4}$ School of Education, Universiti Utara Malaysia, Malaysia \\ ${ }^{2}$ Department of Educational Studies, Universiti Pendidikan Sultan Idris, Malaysia
}

\begin{tabular}{l} 
Article Info \\
\hline Article history: \\
Received Jun 4, 2020 \\
Revised Nov 17, 2020 \\
Accepted Jan 13, 2021 \\
\hline Keywords: \\
Learning facilities \\
Malaysia \\
Pedagogical knowledge \\
Tahfiz \\
Teaching quality
\end{tabular}

\section{Article history:}

Received Jun 4, 2020

Revised Nov 17, 2020

Accepted Jan 13, 2021

\section{Keywords: \\ Malaysia \\ Tahfiz}

\begin{abstract}
The purpose of this study was to examine the relationship between teachers' pedagogical knowledge, learning facilities and the teaching quality of teachers in the Ulul Albab Tahfiz Model (TMUA) schools in Malaysia. The data were collected using a set of questionnaires which probed on the respondents' demographic information as well as on their pedagogical knowledge, learning facilities and teaching quality. The respondents comprised of 144 teachers from three schools involved in TMUA program. The data obtained were processed and analysed through the Partial Least Squares Structural Equation Modelling (PLS-SEM) using SmartPLS 3.0 software. The results show that there is a significant relationship between teachers' pedagogical knowledge, educational facilities and the quality of teaching. The implication of this study is that teachers are aware of the importance of pedagogical knowledge in improving teaching quality when implementing the TMUA program.
\end{abstract}

This is an open access article under the CC BY-SA license.

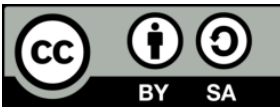

\author{
Corresponding Author: \\ Muhd Zulhilmi Haron \\ School of Education \\ Universiti Utara Malaysia \\ 06010 Sintok, Kedah, Malaysia \\ Email: mizhar1411@yahoo.com
}

\section{INTRODUCTION}

The 4th shift in the Malaysian Education Blueprint 2013-2025 (PPPM 2013-2025) puts a focus on transforming teaching into a profession of choice. This reflects the commitment of the Ministry of Education (MOE) to empower the teachers as part of the government's aspiration to develop first class human capitals. The development and empowerment of human capital need to start from providing quality teaching in schools. In this regard, quality teachers are the first step in improving the quality of education. In line with this shift, the MOE aims to ensure that teachers focus on teaching and facilitating a competency and performance-based career path.

Slavin [1] argued that the quality of education in schools can be assessed based on four aspects which are quality of teaching, level of teaching, rewards and sufficient time allocation. The quality of teaching reflects the ability of a teacher to plan and implement the teaching and learning process in the classroom. The quality of teaching is also closely related to how teachers are trained. Thus, teachers' teaching method is a significant contributor to the quality of teaching.

Quality teachers are required to master several skills including content mastery, pedagogical knowledge of teaching methods [2] and classroom management. Shulman [3] listed seven domains of basic knowledge required by teachers, which are content knowledge, general pedagogical knowledge, curriculum knowledge, content and pedagogical knowledge, knowledge of students' background, knowledge of 
educational context and knowledge of educational goals. The lack of pedagogical knowledge will directly impact the quality of teaching and learning provided for students. This indicates the need for teachers to have a high level of pedagogical knowledge so that they can use effective teaching approaches to facilitate learning in the classroom.

Studies on the level of teachers' pedagogical knowledge are important benchmarks in determining a teacher's ability to provide quality teaching. Researchers believe teachers' pedagogical knowledge is an important determinant of quality teaching in the classroom [4]. In addition, sufficient and well-maintained learning facilities can also improve the quality of teaching. In an effort to attract students' attention and diversify classroom activities, teachers need to utilise various resources available to enhance learning effectiveness and students' self-regulation ability [5]. Furthermore, in today's technological world, teachers should use technology to facilitate interactive learning both in and outside of the classroom [6]. According to study by Haron [7], among the main learning facilities used by teachers include classrooms, resource centres, teaching aids and textbooks. Their study further discussed the role of learning facilities in improving the quality of teaching among teachers in Ulul Albab Tahfiz Model (TMUA) schools in Malaysia.

The TMUA program is one of the initiatives by the MOE to develop student talent and potential by integrating the tahfiz stream with the academic stream. To date, there are 15 secondary schools in Malaysia that were selected to implement the Tahfiz Integrated Curriculum (KBT). The TMUA program combines three learning approaches namely, Quranic-based learning, Ijtihadic-based learning and Encyclopaedic-based learning. The TMUA program is implemented as an effort to produce students who can memorize all 30 juz (chapters) of the Quran throughout the five years of their high school education [8]. The aim of implementing this program is to make Malaysia a world-class Islamic education hub by offering a balanced, progressive and dynamic education system.

Drawing on Shulman's [3] study, there are numerous studies on teacher pedagogical knowledge in different fields, which include the Islamic Education [9], Arabic [10], Language [11], History [12], Mathematics [2, 13], Syariah [14] and Visual Arts Education [15]. However, there are still limited studies on the relationship between teacher pedagogical knowledge and teaching quality, especially among teachers in schools involved in TMUA. It is therefore important that this study is carried out to identify the level of teacher's pedagogical knowledge and the current state of learning facilities in these schools, as well as their relationship with the quality of teaching in the classroom.

\section{RESEARCH METHOD}

This study was a survey research using the deductive descriptive method [16]. The study was initiated by formulating two hypotheses. This was followed by conducting an empirical measurement of the survey data followed by a critical analysis. This study used the cross-sectional survey method where data were collected once from one sample at a time [17].

The study was conducted in Three Religious National Secondary Schools (SMKA) under the supervision of the MOE. These schools are located in different zones. All three schools are in the first cohort involved in the TMUA program and produced the first batch of students after five years of implementation. This study used proportionate stratified random sampling. The sample for this study comprises of 144 teachers out of the total population of 234 .

\subsection{Study respondents}

The distribution of respondents according to schools indicates that 49 of the 144 respondents (34.0\%) are from SMKA X, 50 (34.7\%) from SMKA Y and 45 from (31.3\%) SMKA Z. In term of gender, 90 $(62.5 \%)$ of the respondents are male, while the remaining $54(37.5 \%)$ respondents are female. In terms of their teaching experience, $76(52.8 \%)$ of the respondents have been teaching for 1-3 years (novice teachers) while 68 teachers $(47.2 \%)$ have 4-6 years of teaching experience (experienced teachers).

\subsection{Research instrument}

The items in the study instrument were adapted from several previous studies [18-21]. The items were modified to ensure their relevance to the research questions and hypotheses. The instrument was then reviewed by 9 experts comprising of lecturers from public universities, teachers' training institutes, administrators and policy makers in the Ministry of Education as well as expert teachers in schools. The questionnaire was divided into two sections; Part I and Part II. Part I contains items related to the respondents' demographic backgrounds while items in Part II focus on three constructs which are teacher pedagogical knowledge (7 items), learning facilities (18 items) and teaching quality (21 items). Cronbach's alpha value for all of the items was high at 0.837 . 


\subsection{Data analysis}

Partial Least Squares Structural Equation Modelling (PLS-SEM) using SmartPLS 3.0 software was implemented to evaluate the measurement model and the structural model of this study. PLS-SEM was chosen as the method for analysing the data due to the fact that PLS-SEM is a robust multivariate analysis method despite the minimal requirement for sample size and data validity [22]. Furthermore, PLS-SEM is more relevant to the nature of this study because of its ability to provide better predictions in order to examine the relationship between teachers' pedagogical knowledge, learning facilities and teaching quality. PLS-SEM maximises the variance explained by endogenous latent variables through ordinary least squares (OLS) regression [22].

\section{RESULTS}

In this section, results of the research were analyzed based on the assessment of the measurement model followed by the assessment of the structural model for hypothesis testing.

\subsection{Assessment of the measurement model}

In evaluating the measurement model, the values of factor loading, composite reliability (CR) and average extracted variance (AVE) are often assessed for internal consistency and convergent validity of the model. The suggested factor loading values are $>0.5$, the $C R>0.7$ and the AVE $>0.5$ [23]. Further, the Learning Facilities and Teaching Quality have been conceptualized as second-order constructs for this study. Thus, the researcher followed the method suggested in the PLS literature, which is the repeated indicator approach to modelling second-order factors in the PLS analysis. Overall, two items (C12 and C23) were deleted due to low factor loadings in order to achieve the recommended values for CR and AVE. Table 1 shows that the results of the measurement model exceeded the recommended values, thus indicating satisfactory convergent validity.

After confirming the convergent validity, we proceeded with the evaluation of the discriminant validity. Discriminant validity is the extent to which items differentiate between constructs or measure distinct concepts in the model [23]. In determining the discriminant validity, the heterotrait-monotrait (HTMT) ratio has recently been identified as a preferred criterion when compared to other conventional evaluation methods such as the Fornell-Larcker criterion [24]. In order to establish discriminant validity, previous research suggested two distinct HTMT criterion thresholds of 0.85 and 0.90 [24]. The existing studies uses the stricter threshold of 0.85 to determine discriminant validity. Consequently, discriminant validity was established for the model in this study as all HTMT criterion results (Table 2) are below the critical value of 0.85 . 
Table 1 . The measurement model of convergent validity

\begin{tabular}{|c|c|c|c|c|c|}
\hline First-order construct & Second-order construct & Item & Loadings & $\mathrm{CR}$ & AVE \\
\hline \multirow[t]{5}{*}{ Resource centre } & & B01 & 0.745 & 0.871 & 0.578 \\
\hline & & B02 & 0.826 & & \\
\hline & & B03 & 0.846 & & \\
\hline & & B04 & 0.743 & & \\
\hline & & B05 & 0.619 & & \\
\hline \multirow[t]{5}{*}{ Classroom } & & B06 & 0.568 & 0.857 & 0.550 \\
\hline & & В07 & 0.863 & & \\
\hline & & B08 & 0.835 & & \\
\hline & & B09 & 0.719 & & \\
\hline & & B10 & 0.685 & & \\
\hline \multirow[t]{4}{*}{ Teaching aids } & & B11 & 0.908 & 0.955 & 0.840 \\
\hline & & B12 & 0.928 & & \\
\hline & & B13 & 0.929 & & \\
\hline & & B14 & 0.901 & & \\
\hline \multirow[t]{8}{*}{ Text book } & & B15 & 0.704 & 0.845 & 0.579 \\
\hline & & B16 & 0.737 & & \\
\hline & & B17 & 0.878 & & \\
\hline & & B18 & 0.711 & & \\
\hline & Learning Facilities & Resource centre & 0.769 & 0.834 & 0.564 \\
\hline & & Classroom & 0.826 & & \\
\hline & & Teaching aids & 0.841 & & \\
\hline & & Text book & 0.524 & & \\
\hline \multirow[t]{7}{*}{ Teachers' pedagogical knowledge } & & B21 & 0.843 & 0.948 & 0.722 \\
\hline & & B22 & 0.841 & & \\
\hline & & B23 & 0.855 & & \\
\hline & & B24 & 0.892 & & \\
\hline & & B25 & 0.831 & & \\
\hline & & B26 & 0.849 & & \\
\hline & & B27 & 0.834 & & \\
\hline \multirow[t]{5}{*}{ Technique } & & $\mathrm{C} 01$ & 0.741 & 0.851 & 0.534 \\
\hline & & $\mathrm{C} 03$ & 0.727 & & \\
\hline & & $\mathrm{C} 04$ & 0.817 & & \\
\hline & & $\mathrm{C} 05$ & 0.736 & & \\
\hline & & $\mathrm{C} 11$ & 0.620 & & \\
\hline \multirow[t]{4}{*}{ Resource } & & $\mathrm{C} 20$ & 0.584 & 0.825 & 0.547 \\
\hline & & $\mathrm{C} 21$ & 0.817 & & \\
\hline & & $\mathrm{C} 22$ & 0.675 & & \\
\hline & & $\mathrm{C} 24$ & 0.851 & & \\
\hline \multirow[t]{13}{*}{ Assessment } & & $\mathrm{C} 35$ & 0.655 & 0.928 & 0.565 \\
\hline & & $\mathrm{C} 36$ & 0.674 & & \\
\hline & & $\mathrm{C} 37$ & 0.796 & & \\
\hline & & $\mathrm{C} 38$ & 0.719 & & \\
\hline & & C39 & 0.774 & & \\
\hline & & $\mathrm{C} 40$ & 0.683 & & \\
\hline & & $\mathrm{C} 41$ & 0.749 & & \\
\hline & & $\mathrm{C} 42$ & 0.777 & & \\
\hline & & $\mathrm{C} 43$ & 0.851 & & \\
\hline & & $\mathrm{C} 44$ & 0.814 & & \\
\hline & Teaching Quality & Technique & 0.538 & 0.771 & 0.541 \\
\hline & & Resource & 0.681 & & \\
\hline & & Assessment & 0.933 & & \\
\hline
\end{tabular}

Notes: Items C12 and C23 were deleted due to low loadings. CR=Composite Reliability; AVE=Average Variance Extracted.

Table 2. The HTMT criterion of discriminant validity

\begin{tabular}{cccc}
\hline Constructs & Teachers' pedagogical knowledge & Learning facilities & Teaching quality \\
\hline Teachers' pedagogical knowledge & & & \\
Learning facilities & 0.375 & \\
Teaching quality & 0.526 & 0.418 \\
\hline
\end{tabular}

\subsection{Assessment of the structural model}

Primarily, the $R^{2}$ value was calculated to evaluate the predictive power of the structural models. $R^{2}$ shows the amount of variance explained of the exogenous variables to the endogenous variable. Together, these three variables in this study explained $27.8 \%$ of the variance (Figure 1). For the assessment of the hypothesized relationships, the path estimates and t-statistics were computed using a bootstrapping technique with a re-sampling of 5000. Table 3 presents the analysis of the structural model. The analysis showed that Teachers' Pedagogical Knowledge $(\beta=0.421, \mathrm{p}<.01)$ and Learning Facilities $(\beta=0.207, \mathrm{p}<.01)$ were positively related to Teaching Quality in TMUA schools. Both hypotheses (H1 and $\mathrm{H} 2$ ) developed in this study were therefore supported. 


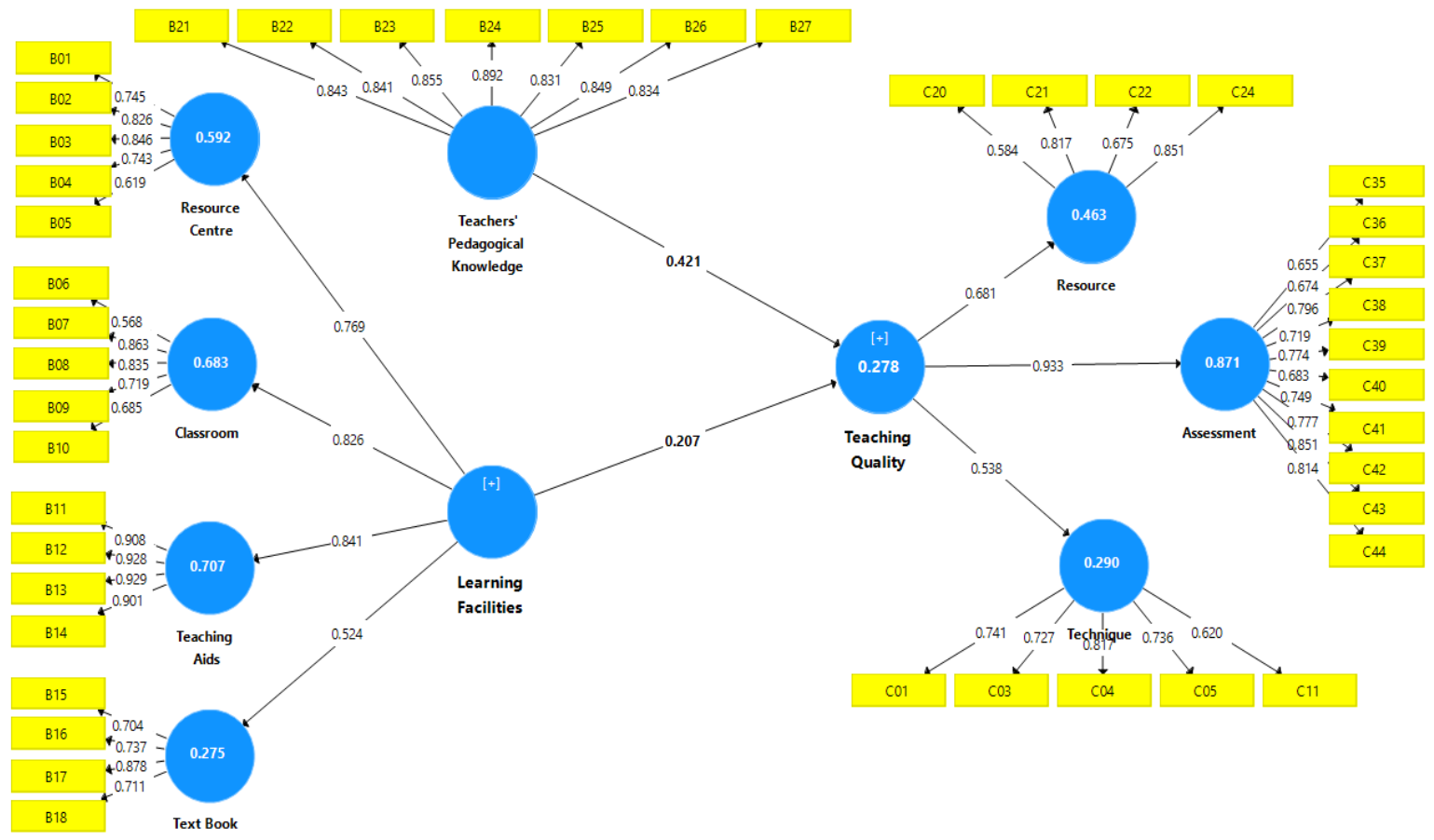

Figure 1. PLS algorithm of structural model analysis

Table 3. Results of the hypothesis analysis

\begin{tabular}{lccccc}
\hline Hypothesis & Std. Beta & SE & $t$-Value & $p$-Value & Decision \\
\hline H1: Teachers' Pedagogical Knowledge -> Teaching Quality & 0.421 & 0.098 & 4.288 & 0.000 & Supported \\
H2: Learning Facilities -> Teaching Quality & 0.207 & 0.080 & 2.596 & 0.009 & Supported \\
\hline
\end{tabular}

Then, the $\mathrm{Q}^{2}$ value or the predictive relevance was calculated by using the blindfolding procedure with a distance value of 7 [23]. The measurement of blindfolding is based on the sample reuse technique, eliding part of the data matrix, estimating the model parameters and predicting the elided part using the estimates [23]. Since the $\mathrm{Q}^{2}$ value of 0.089 is greater than 0 [25] with just one endogenous construct of Teaching Quality, the model was consider as having adequate predictive power.

\section{DISCUSSION}

This study found a significant and positive relationship between teachers' pedagogical knowledge and learning facilities towards teaching quality of TMUA teachers. Therefore, teachers need to be more proactive to increase their pedagogical knowledge to enhance their teaching effectiveness and improving their teaching quality [26-28]. This is especially true for novice teachers, as they need to take a proactive role in diversifying their teaching methods to capture the interest of the millennial student population [2]. In this light, novice teachers could discuss and observe the teaching and learning process of more senior teachers to gain more experience and output on how to facilitate effective teaching and learning [29, 30]. This effort would be more effective with the aid of technological tools in learning process because this strategy might increase students' interest in tahfiz Al-Quran [6].

Another interesting finding is that well-equipped learning facilities can help teachers improve the quality of their teaching [31]. Therefore, learning facilities in schools need to be sufficient and well maintained [32], so that they could be used at an optimal level and in-line with the latest development of time as well as may increase teachers' empowerment at school [33]. Teachers also need to be more creative and innovative in order to provide the most current and interactive teaching aids, as well as to ensure their classrooms are conducive for learning, for a better development of TMUA students [34]. 


\section{CONCLUSION}

The results of this study show that teachers should play an active role to increase their pedagogical and content knowledge to ensure they can provide an engaging and meaningful learning experience for the students, hence, enhancing their teaching quality. In relation to this, TMUA teachers should have a positive attitude and the drive to enhance their current knowledge and skills to ensure engaging lessons to increase the interest of students to study subjects like Hifz Quran and Maharat Al-Quran.

Teachers should also make use the learning facilities provided by diversifying the use of teaching aids in their lessons. Excessive use of textbooks should be avoided by translating the content of the textbook into teaching aids. In this context, teachers need to critically choose, adapt and apply the most suitable teaching materials, and select the teaching methods, strategies or techniques that best suit the students' needs. The use of varied and interactive teaching aids could capture the students' interest and focus in every step of teaching.

Subsequently, schools should take the initiative to organize a series of on-going training sessions consistently. Training sessions can be an effective medium for experienced teachers to share their teaching techniques, tips and expertise with novice teachers. These activities could help teachers to plan effective lessons and enhance their teaching effectiveness and quality. Later, teachers' confidence and efficacy in coping with a diverse teaching environment could be enhanced.

The MOE should also implement continuous, consistent and systematic initiative to increase teachers' professionalism and to empower the teaching profession. The MOE should fulfil the needs of TMUA teachers, specifically in the field of innovation. This includes finding solutions to help rapid memorization of Quranic verses in the context of implementing the TMUA program. The MOE could also collaborate with the Ministry of Higher Education (MoHE) to offer tahfiz-based program at the undergraduate and postgraduate level to train teachers with effective pedagogical knowledge and fulfil the increasing needs for tahfiz teachers in schools.

\section{ACKNOWLEDGEMENTS}

The authors would like to thanks the various parties that supported this research, in particular all teachers in the TMUA schools and for the Ministry of Education Malaysia.

\section{REFERENCES}

[1] Slavin, R., "A theory of school and classroom organization,” Educational Phsychologist, vol. 22, pp. 89-108, 1991.

[2] Suaidi, M. S., "Pedagogical Content Knowledge among The Novice Teacher and Expert Teachers in Schools within Hulu Langat," Prosiding Seminar Pendidikan Serantau ke-VIII, 2017, pp. 1-6.

[3] Shulman, L., "Knowledge and teaching: Foundation of new reform," Havard Educational Review, vol. 57, no. 1, pp. 1-22, 1987.

[4] Syed Idrus, S. K. and Awang, M. I., "Retrospektif kualiti pengajaran pensyarah berdasarkan perspektif guru pelatih di Institut Pendidikan Guru wilayah utara Malaysia," Jurnal Penyelidikan Dedikasi, vol. 10, pp. 26-42, 2016.

[5] Zalli, M. M. M., Nordin, H., and Hashim, A.W., "Online self-regulated learning strategies in MOOCs: A measurement model," International Journal of Emerging Technologies in Learning, vol. 15, no. 8, pp. 255-263, 2020.

[6] Haron, M. Z., Othman, M. K., and Awang, M. I., "Technology-assisted teaching aids in teaching and learning: Evidence from the Malaysian Tahfiz Ulul Albab Model (TMUA)," International Journal of Innovative Technology and Exploring Engineering, vol. 8, no. 12, pp. 4401-4404, 2019.

[7] Haron, M. Z., Zalli, M. M. M., Othman, M. K., and Awang, M. I., "School's facilities and achievement of students in Ulul Albab Model Tahfiz schools in Malaysia: A mediating roles of satisfaction," International Journal of Scientific \& Technology Research, vol. 9, no. 2, pp. 3026-3030, 2020.

[8] Ministry of Education Malaysia. Surat pekeliling ikhtisas Kementerian Pendidikan Malaysia bilangan 1 tahun 2016: Pelaksanaan Tahfiz. Model Ulul Albab di sekolah menengah Kementerian Pendidikan Malaysia, 2016.

[9] Yunus, A. and Tamuri, A. H., "Pengetahuan pedagogikal kandungan (PPK) pengajaran akidah: kajian kes guru cemerlang Pendidikan Islam," Journal of Islamic and Arabic Education, vol. 2, no. 2, pp. 13-30, 2010.

[10] Nik Yusoff, N. M. R., Hasan, N., and Afifi, M., "Pengetahuan pedagogi isi kandungan (PPIK) pengajaran Bahasa Arab," Persidangan Kebangsaan Pengajaran dan Pembelajaran Bahasa Arab (PKEBAR'12), 2012.

[11] Mahamod, Z. and Nor, M., "Penguasaan pengetahuan pedagogi kandungan guru Bahasa Iban," GEMA Online TM Journal of Language Studies, vol. 12, no. 2, pp. 593-608, 2012.

[12] Suhairi, M. H. M. and Ahmad, A., "Pengaruh pengetahuan isi kandungan terhadap aplikasi pengajaran yang berkesan dalam kalangan guru-guru sejarah," International Conference on Global Education V., Padang, 10-11 April, 2017, pp. 2457-2474.

[13] Aksu, Z., "Pre-service mathematics teachers' pedagogical content knowledge regarding student mistakes on the subject of circle," International Journal of Evaluation and Research in Education (IJERE), vol. 8, no. 3, pp. 440-445, 2019. 
[14] F. Fatah, et al., "Pedagogical Knowledge of Syariah Subject using Integrated Dini Curriculum at Government Aided Educational Religious School," International Journal of Education, Psychology and Counseling, vol. 4, no. 29, pp. 1-11, 2019.

[15] R. M. Nor, et al., "Pedagogical Content Knowledge of Secondary School Visual Arts Teachers," Jurnal Pendidikan Malaysia, vol. 44, no. 1, pp. 137-150, 2019.

[16] Neuman, W. L., Social research methods: Quantitative and qualitative approaches, 7th ed. Needham Height, MA: Allyn and Bacon, 2011.

[17] Creswell, J. W., Educational research: Planning, conducting and evaluating quantitative and qualitative research, 4th ed. Boston, MA: Pearson Education, 2012.

[18] A. Hashim, "Penilaian pelaksanaan kurikulum tahfiz Al-Quran di Darul Quran JAKIM dan Maahad Tahfiz AlQuran negeri,” Ph.D. Dissertation, Universiti Kebangsaan Malaysia, Malaysia, 2010.

[19] N. H. F. Talib, "Penilaian pelaksanaan kurikulum TITAS di Politeknik kementerian pengajian tinggi Malaysia," Ph.D. Dissertation, Universiti Kebangsaan Malaysia, Malaysia, 2013.

[20] A. Jaafar, "Penilaian pelaksanaan kurikulum pendidikan Islam sekolah menengah berasaskan Model Context-InputProcess-Product (CIPP),” Ph.D. Dissertation, Universiti Utara Malaysia, Malaysia, 2015.

[21] M. Z. Ismail, "Penilaian pelaksanaan program ijazah sarjana muda pendidikan di Institut Pendidikan Guru Darulaman (IPDA)," Ph.D. Dissertation, Universiti Utara Malaysia, Malaysia, 2019.

[22] Hair, J. F., Ringle, C. M., and Sarstedt, M, "PLS-SEM: Indeed a silver bullet," Journal of Marketing Theory and Practice, vol. 19, no. 2, pp. 139-152, 2011.

[23] Hair, J., Hult, G., Ringle, C., and Sarstedt, M., A primer on partial least squares structural equations modeling (PLS-SEM), 2nd ed. Los Angeles, CA: SAGE, 2017.

[24] Henseler, J., Ringle, C. M., and Sarstedt, M., "A new criterion for assessing discriminant validity in Variance-based Structural Equation Modeling," Journal of the Academy of Marketing Science, vol. 43, no. 1, pp. 115-135, 2015.

[25] C. Fornell and D. F. Larcker, "Evaluating structural equation models with unobservable variables and measurement error," Journal of Marketing Research, vol. 18, no. 1, pp. 39-50, 1981.

[26] A. P. Sasmito, et al., "Conceptual model for improving quality of teacher in Indonesian vocational school," International Journal of Evalution and Research in Education (IJERE), vol. 9, no. 1, pp. 39-44, 2020.

[27] Talling, M., Hamzah, A., Khairani, A. Z., Zalli, M. M. M., and Awang, Z., "Pedagogical strategies for teaching counselling theoretical courses: The needs to nurture psychological aspect," Journal of Critical Reviews, vol. 7, no. 9, pp. 672-678, 2020.

[28] Huda, M., Hashim, A., Teh, K. S. M., Shankar, K., Ayshwarya, B., Nguyen, P. T., Hashim, W., and Maseleno, A., "Learning quality innovation through integration of pedagogical skill and adaptive technology," International Journal of Innovative Technology and Exploring Engineering, vol. 8, (9 Special Issue 3), pp. 1538-1541, 2019.

[29] Wolff, C. E., van den Bogert, N., Jarodzka, H., and Boshuizen, H. P., "Keeping an eye on learning: Differences between expert and novice teachers' representations of classroom management events," Journal of Teacher Education, vol. 66, no. 1, pp. 68-85, 2015.

[30] Wolff, C. E., Jarodzka, H., and Boshuizen, H. P., "See and tell: Differences between expert and novice teachers' interpretations of problematic classroom management events," Teaching and Teacher Education, vol. 66, pp. 295-308, 2017.

[31] N. C. Hassan, et al., "Tahfiz Students' Interest and Form of Supports Received," Journal of Humanities, Language, Culture and Business, vol. 1, no. 2, pp. 67-78, 2017.

[32] Sobandi, A., Yuniarsih, T., and Adman, R., "Learning facilities: Can it improve the vocational school productivity?" Journal of Educational and Social Research, vol. 10, no. 4, pp. 146-155, 2020.

[33] Yusoff, S. M., Ariffin, T. F. T., and Zalli, M. M. M., "School Participation Empowerment Scale (SPES) Adaptation for Teachers in Malaysia," Universal Journal of Educational Research, vol. 8, no. 5, pp. 1821-1830, 2020.

[34] Haron, M. Z., Othman, M. K., and Awang, M. I., "Keperluan penilaian pelaksanaan kurikulum Tahfiz Model Ulul Albab (TMUA) sekolah menengah Kementerian Pendidikan Malaysia," Practitioner Research, vol. 1, pp. 289-316, 2019. 